\title{
Peliputan Isu Lingkungan dan Pembangunan Berkelanjutan
}

\begin{abstract}
Alex Sobur
ABSTRACT

The press role, in order to support development process, is undeniable. Such was the case of environmental issue when the news of possible environmental damage appeared as important reports in the newspaper. Over the last 35 years, environmental issues has moved from periphery to central of state policy - thanks to the press who consistently reported and develop a kind of environmental journalism. This article describes characteristics of environmental report which concentrated more on the cause instead of effect.
\end{abstract}

Kata kunci: lingkungan, pembangunan, pers

\section{Pendahuluan}

Berbagai berita bencana belakangan ini banyak menghiasi media massa kita. Kita tampaknya masih sulit melupakan bencana lingkungan hidup yang pernah terjadi di berbagai belahan dunia lain seperti Chernobyl, Three Mile Island, Love Canal, Bhopal di India, Times Beach di Missouri, sampai peracunan merkuri di Minamata Jepang, rumah-rumah yang tercemar radon, pembuangan dioxin dalam teluk.

\section{Isu Lingkungan sebagai Berita}

Dalam perspektif jurnalistik, bencana seperti itu termasuk kategori berita yang tidak terduga. Karena sifatnya yang tidak diduga, berita-berita lingkungan hidup semacam ini menuntut keahlian tersendiri bagi para wartawannya untuk meliputnya. Terkait dengan peristiwa ini, semakin besar korban yang ditimbulkannya atau semakin besar harta atau benda yang rusak dan musnah, semakin besar pula nilai beritanya.

Itu pula sebabnya, isu-isu lingkungan hidup dan kesehatan kini banyak disajikan sebagai berita penting di halaman muka surat kabar, tak lagi "dilempar" ke bagian belakang halaman surat kabar atau dijadikan buntut liputan berita, seperti kecenderungan yang terjadi sebelumnya. Kita melihat, dalam waktu sekurangnya 35 tahun belakangan ini posisi lingkungan hidup telah bergeser dari "pinggiran" menuju ke arus tengah pembangunan. Bahkan, keduanya dapat larut melebur menjadi "pembangunan berwawasan lingkungan". Seperti diibaratkan oleh mantan Menteri Negara Kependudukan dan Lingkungan Hidup Emil Salim, lingkungan hidup dan pembangunan menjadi seperti gula dalam teh manis.

Jika pergerakan atau pergeseran isu lingkungan hidup dari posisi "pinggiran" ke posisi 
"sentral" dalam waktu 35 tahun itu dianggap cepat, maka salah satu penyumbang penting yang patut diberi penghargaan adalah peranan pers atau media massa. Media massa diakui oleh LSM Walhi (Wahana Lingkungan Hidup Indonesia) sebagai alat yang paling efektif untuk melibatkan publik dalam perdebatan mengenai pembangunan berkelanjutan (Atmakusumah, 1996).

\section{Peranan Pers}

Peranan pers untuk mendukung pembangunan tidak dapat disangsikan lagi. Sejak terbitnya buku Mass Media and National Development yang ditulis Wilbur Schramm (1964), banyak program pembangunan yang melibatkan pers atau media massa. Bahkan, pada tahun 1970an, berkembang pula jurnalistik pembangunan, yang menyadarkan pers bahwa bukan hanya berita yang "luar biasa" atau "yang aneh" dan "yang terkecuali" yang memperoleh tempat untuk pemberitaan. Berita-berita pembangunan, aspirasi masyarakat untuk memperbaiki diri, perbaikan gizi dan perbaikan standar kehidupan, merupakan bahan pemberitaan, di samping pendalaman masalah-masalah tadi.

Pada tahun 1980-an, kesadaran orang terhadap "lingkungan" mulai tumbuh. Tak terkecuali dunia pers, tentunya, mulai memberikan liputan terhadap masalah lingkungan. Pencemaran laut oleh buangan minyak dan kecelakaan kapal-kapal tanker mendapatkan tempat pemberitaan yang besar di surat kabar. Pemberitaan masalah pencemaran lingkungan mulai mendapatkan tempat, dan bahkan karena dampak dan kerugian yang ditimbulkannya, sering berita pencemaran lingkungan tadi mendapat tempat sebagai berita utama.

Bagaimanakah peranan pers dalam mendukung pembangunan berkelanjutan?

Pertama-tama, kita perlu menyamakan persepsi tentang apa itu pembangunan berkelanjutan. Seperti halnya dengan banyak istilah populer lainnya, "pembangunan berkelanjutan", sesungguhnya, merupakan kata bersayap. Istilah ini menarik, terasa membawa muatan atau janji baru, dan kedengarannya memang membawakan suatu aspirasi bersama, sehingga semakin banyak dipakai dalam komunikasi sosial dan media massa.

Tetapi, sebagaimana umumnya kata bersayap, istilah ini juga mudah disalahartikan dan belum dipahami secara luas. Alwi Dahlan (1992), misalnya, mencatat, betapa banyak orang menggunakan istilah "pembangunan berkelanjutan" hanya sebagai pengganti istilah pembangunan berwawasan lingkungan, atau kegiatan pembangunan yang tidak membawakan dampak fisik terhadap lingkungan hidup. Ada pula yang mengartikan sebagai sekadar upaya pelestarian lingkungan alam. Bahkan, tidak jarang yang mengira bahwa istilah ini menggambarkan laju pertumbuhan ekonomi yang tinggi dan berkesinambungan — jadi justru berbeda dari konsepnya semula.

Jika terus menerus dipersepsi seperti itu, maka, tentu saja, pembangunan berkelanjutan dapat kehilangan makna dan berubah menjadi sekadar slogan yang tidak akan pernah tercapai. Agar pembangunan berkelanjutan dapat dilaksanakan dan berhasil sebagai strategi, pemaknaan istilah ini perlu diikuti dengan pengertian yang memadai pada masyarakat luas mengenai relevansi dan urgensinya dalam kehidupan nyata. Kesadaran akan hal ini hendaknya menjadi sedemikian rupa, sehingga ia dijadikan konteks dan tolok-ukur dalam menilai perkembangan keadaan, pelaksanaan pembangunan, dan kegiatan masyarakat seharihari. Ini berarti, informasi pembangunan berkelanjutan perlu tersebar luas, tersedia secara teratur, dan menjadi kebutuhan informasi segenap kalangan masyarakat. Dengan kata lain, pembangunan berkelanjutan perlu masuk ke dalam agenda komunikasi sosial dan media komunikasi massa. Segi-segi atau aspeknya hendaknya menjadi salah satu pertimbangan penting dalam peliputan atau pemberitaan.

Apa itu informasi pembangunan berkelanjutan? Pada intinya, pembangunan berkelanjutan merupakan alternatif terhadap pandangan pembangunan yang lalu. Selama ini, pembangunan mengutamakan pertumbuhan ekonomi yang cepat untuk meningkatkan kesejahteraan penduduk hari ini dengan menguras sumber daya alam secara berlebihan, sehingga 
merusak kemampuan alam memperbarui diri dan menunjang kehidupan penduduk masa depan (Dahlan, 1992:32-33). Dalam konsep baru ini, pemanfaatan alam dilakukan bukan saja tanpa merusak, tetapi sekaligus juga menjaga atau mengembangkan keberlanjutan kemampuannya untuk kebutuhan pembangunan generasi mendatang.

Tentang bagaimana peranan pers dalam mendukung pembangunan yang berkelanjutan, yang jelas, pers harus dapat lebih berperan aktif dalam meliput masalah-masalah tadi. Meliput masalah lingkungan dan pembangunan sudah merupakan berita-berita yang bisa menarik bagi wartawan. Berita-berita lingklungan dan pembangunan sudah merupakan berita-berita yang dapat menarik perhatian pembaca. Sama kuatnya ditinjau dari segi berita sebagai komoditas, dengan seks dan kekerasan atau sport. Betapa tidak, marilah kita lihat, misalnya, rangkaian peristiwa yang pernah menjadi headline dalam surat-surat kabar (Assegaff, 1992:37), seperti:

(1) Kelaparan yang melanda Afrika, akibat proses terjadinya gurun pasir di Sahel.

(2) Peristiwa Bhopal yang menimbulkan korban empat ratus orang cacat buta dan ratusan meninggal.

(3) Pencemaran minyak di laut (peristiwa Valdez) yang telah menghabiskan biaya lebih dari 1.2 miliar US dolar.

(4) Kebocoran radioaktif di PLTN Chernobil Rusia.

Dari yang disebutkan di atas, liputan pers terhadap masalah pembangunan dan lingkungan hidup, merupakan liputan yang menarik dan terbukti menarik minat pembaca. Bahkan, sering terjadi, pemberitaan lingkungan kemudian berkembang menjadi pemberitaan politik. Lihat saja, misalnya, masalah-masalah isu kalangan LSM lingkungan hidup; yang menjadi isu politik. Gerakan "The Green Peace" sering terkait pada politik dan menjadi pemberitaan politik.

Informasi pembangunan berkelanjutan sebenarnya terkandung pada setiap informasi yang penting bagi manusia dan masyarakat. Karena pembangunan berkelanjutan mempengaruhi kepentingan kehidupan semua orang, maka pada informasi pembangunan manapun sebetulnya melekat butir-butir yang relevan bagi pembangunan berkelanjutan.

Jika seperti itu, bisa pula dikatakan bahwa setiap informasi pembangunan yang layak beritaekonomi, politik, sosial, budaya-banyak sedikitnya mengandung sisi yang relevan dan potensial dipandang dari salah satu unsur pembangunan berkelanjutan: apakah kependudukan, lingkungan hidup, ataukah pembangunan. Meski demikian, kandungan muatan yang relevan dengan pembangunan berkelanjutan tentu mempunyai bobot yang berbeda-beda dan tidak semuanya mencukupi, sehingga harus diperlakukan sebagai informasi pembangunan berkelanjutan dan diberitakan secara seperti itu. Jika semua butir berita diolah menjadi berita pembangunan berkelanjutan, maka pemahaman masyarakat tentang pembangunan berkelanjutan itu akan menjadi rancu dan kabur.

Bahkan, Walhi pernah mengingatkan, untuk merangsang perdebatan, liputan media massa tidaklah cukup apabila hanya sekadar berupa berita, melainkan perlu berbentuk kisah dan feature berkedalaman.

Apa yang diharapkan Walhi kiranya tidaklah berlebihan. Di tengah-tengah suasana hati masyarakat kita yang kian resah karena kondisi lingkungan mereka, maka para wartawan dan redaktur media massa tidak bisa lagi memakai caracara "berdasarkan perkiraan dan naluri" ketika melaporkan informasi pembangunan berkelanjutan, utamanya isu lingkungan hidup. Berita atau laporan yang disajikan secara teknis harus cermat, objektif, berimbang, dan bertanggung jawab. Mutu laporan, bagaimanapun, akan mempengaruhi pendapat masyarakat, dan dari pendapat masyarakat itu kerap muncul politik masyarakat. Namun hanya sedikit saja surat kabar yang dapat menempatkan wartawannya dengan tugas penuh pada peliputan berita lingkungan. Akibatnya, sudah bisa ditebak, berita atau laporan yang dihasilkannya menjadi kurang cermat, kurang objektif, dan tidak berimbang.

Simaklah, misalnya, berita tentang 
perambahan hutan yang makin parah di kawasan Bandung selatan yang telah merusak lahan konservasi sebagai daerah tangkapan air bagi Sungai Citarum. Padahal, demikian bunyi berita tersebut, sungai terpanjang di Jawa Barat ini merupakan sumber utama pengisi waduk Saguling, Cirata, dan Jatiluhur yang memiliki pembangkit listrik interkoneksi Jawa-Bali.

Pers kita melukiskan kerusakan hutan di Bandung selatan dengan sebuah gambaran hancurnya hutan di Jawa Barat yang makin hari semakin mengkhawatirkan. Kekhawatiran itu didasarkan pada data Dinas Kehutanan Jawa Barat yang menyatakan, dibandingkan lima tahun lalu, lahan kritis di Jawa Barat meningkat seluas 211.603 hektar atau 57,37 persen. Pers nasional memberitakan, akibat yang ditimbulkan bagi lingkungan sekitar hutan yang rusak adalah erosi tanah dan hancurnya ekologi. Contoh nyata yang bisa ditunjukkan adalah menurunnya kualitas air.

Amati pula pelaporan ihwal mencuatnya kembali upaya perlindungan di kawasan Bandung utara yang dikaitkan dengan isu yang lebih luas lagi, yakni upaya perlindungan kawasan Gunung Burangrang, Sunda, Tangkubanparahu dan sekitarnya.

Apa yang kita baca dari kedua berita lingkungan hidup yang dilaporkan pers tersebut? Tampaknya cukup membingungkan juga. Membingungkan, sebab berbeda dengan berita politik atau berita ekonomi, sebagian besar berita lingkungan hidup hanya melaporkan tentang apa yang sedang dan sudah terjadi. Itu pun hanya lewat hasil wawancara tanpa disertai upaya observasi atau terjun langsung ke lapangan, sehingga tidak jelas di mana akar masalahnya. Padahal, berita lingkungan hidup tidak hanya menyangkut peristiwa yang sudah terjadi, tetapi juga yang akan terjadi di masa datang.

Tentu saja, kedua sampel berita tersebut, tidak bisa mewakili seluruh berita lingkungan hidup yang dilaporkan pers kita. Namun, paling tidak, sampel tersebut merefleksikan orientasi pemberitaan pers kita mengenai realitas lingkungan hidup, yang cenderung melaporkan masalah yang sudah terjadi.
Lantas bagaimana sesungguhnya karakteristik peliputan berita lingkungan hidup yang ideal itu? Memang, disebabkan begitu luasnya ruang lingkup bahan lingkungan hidup itu, karena mencakup semua aspek kehidupan, menyebabkan hingga kini belum ada suatu formulasi yang baku. Namun, menurut Steve Klein (1983, dalam Abrar, 1993), berita lingkungan hidup yang ideal adalah berita yang lebih banyak mengungkapkan sebab ketimbang akibat.

\section{Pedoman Peliputan dan Penulisan}

Karena tidak ada formulasi baku, maka beberapa butir penting dalam "Pedoman Peliputan Lingkungan" dan "Petunjuk Penulisan Laporan Lingkungan Hidup" yang dihasilkan oleh lokakarya "Liputan Lingkungan Hidup untuk Media Cetak" di Maninjau, Sumatera Barat, pada 24-29 Oktober 1994, kiranya bisa dijadikan rujukan sederhana sebagai langkah awal untuk memahami persoalan jurnalisme lingkungan.

Beberapa butir penting dari "Pedoman Peliputan Lingkungan", antara lain, menandaskan bahwa masalah lingkungan hidup dan dampaknya dapat meluas melintasi perbatasan wilayah atau negara. Apa yang disebut lingkungan hidup itu sangatlah kompleks, sering bersifat teknis, dan saling berkaitan dengan bidang lain seperti politik, kebudayaan, ekonomi, kesehatan, atau sosial. Singkatnya, masalah lingkungan adalah topik yang bersifat multidisipliner, yang mencakup sains, kedokteran, kesehatan masyarakat, meteorologi, teknik, perencanaan kota, ilmu ekonomi, psikologi, ilmu komunikasi, dan masih banyak lagi segi kehidupan manusia. Oleh karena itu, menjelaskan secara sederhana tidak selalu mudah dan cara penulisan laporannya tidak selalu sama dengan bidang-bidang lain. Dengan demikian, diperlukan suatu arus kesadaran yang terus menerus sampai kita mencapai titik optimal pembangunan sumbersumber daya kita dengan gangguan seminimal mungkin terhadap lingkungan. "Memiliki kesadaran itu adalah tugas reporter masalah lingkungan," begitu kata Mahmoud Abdel Aziz (1987), reporter Harian Al Ahram Kairo, Mesir. 
Selain itu, wartawan perlu terjun langsung ke tempat kejadian untuk menghasilkan liputan lingkungan hidup yang komprehensif. Melihat dengan kepada sendiri adalah cara terbaik untuk melaporkan suatu peristiwa. "Suatu peristiwa tidak berdiri sendiri," demikian tulis Jakob Oetama (1987). Artinya, ia berkaitan dengan beberapa peristiwa lain. Selalu ada kaitan, ada konteks. Reportase komprehensif amat memperhatikan konteks dan kaitan itu. Komprehensif berarti mencakup segala segi.

Kovach dan Rosenstiel (2003) mengibaratkan jurnalisme sebagai kartografi modern. Ia menghasilkan sebuah peta bagi warga untuk mengambil keputusan tentang kehidupan mereka sendiri. Itulah manfaat dan alasan ekonomi kehadiran jurnalisme. Konsep kartografi ini membantu menjelaskan apa yang menjadi tanggung jawab liputan jurnalistik. Seperti halnya peta, nilai jurnalisme bergantung pada kelengkapan dan proporsionalitas. Mengumpamakan jurnalisme sebagai pembuatan peta membantu kita melihat bahwa proporsi dan komprehensivitas adalah kunci akurasi. Laporan komprehensif dapat membantu khalayak ikut "melihat" dan "merasakan" peristiwa yang dilaporkan.

Selanjutnya, walaupun keberimbangan atau objektivitas laporan lingkungan hidup perlu diupayakan sejauh mungkin, wartawan dapat berpihak kepada pendukung dan pembela kelestarian lingkungan hidup. Namun, wartawan harus tetap bersikap jujur dan bertanggung jawab, sehingga dapat tetap mempertahankan kredibilitas liputannya. Dengan konsep objektivitas - meski makna asli dari konsep ini sering disalahpahami, dan sebagian besar bahkan hilang-meminta wartawan mengembangkan sebuah metode untuk secara konsisten menguji informasi-pendekatan transparan menuju bukti-bukti-dengan tepat sehingga bias personal dan bias budaya tidak melemahkan akurasi mereka. Dalam hal tanggung jawab, setiap wartawan-dari redaksi hingga dewan direksi-harus punya rasa etika dan tanggung jawab personal — sebuah panduan moral. Terlebih lagi, mereka punya tanggung jawab untuk menyuarakan sekuat-kuatnya nurani mereka dan membiarkan yang lain melakukan hal serupa.

Hal lain yang tak kurang pentingnya, penyiaran hasil liputan yang tepat waktu dan akurat lebih diperlukan dalam masalah lingkungan hidup dibandingkan dengan penyiaran banyak masalah lain, karena penanggulangan masalah lingkungan hidup sering memerlukan tindakan yang mendesak dan tepat waktu. Langkah awal yang paling tepat adalah mencoba memahami "bahasa risiko" (West, Sandman, Greenberg, 1995).

"Bahasa risiko" memberikan wawasan yang perlu mengenai apa yang sering disalahpahami dan yang sering dibesar-besarkan, yakni mengenai cara kita berkisah tentang dampak pendedahan. Agar dapat menulis sebuah berita dengan cermat, kita harus peka terhadap bahasa dampak dan bahaya. Kita akan segera menemukan bahwa ada dua cara yang amat berbeda untuk bertutur tentang risiko: cara yang satu amat teknis dan kuantitatif; cara kedua amat tidak teknis dan kerap bermuatan emosi. Para ilmuwan dan rakyat biasa sering berselisih paham dalam membicarakan risiko. Pencermatan atas perbedaan-perbedaan ini akan memberi berita yang ditulis wartawan wibawa yang lebih besar dan mengantarkan institusi media tempat wartawan itu bekerja ke jenjang kredibilitas di kalangan narasumber dan pembacanya.

Setelah mencoba memahami beberapa pedoman penting dalam peliputan lingkungan, tahap berikutnya adalah penulisan laporan. Pada tahap penulisan laporan ini, wartawan lingkungan hidup seyogianya mengetahui beberapa petunjuk penting berikut.

Pertama, untuk memperoleh bahan yang memadai bagi laporan lingkungan hidup, wartawan hendaknya mengajukan sebanyak mungkin pertanyaan kepada narasumber. Dengan demikian, ia akan memperoleh kejelasan yang diperlukan untuk menyusun laporan yang dapat dipahami khalayak, terutama khalayak media cetak. Banyaknya pertanyaan yang diajukan akan memberikan pemahaman yang lebih baik kepada wartawan mengenai masalah lingkungan hidup. Lebih baik mengajukan pertanyaan "sepele" kepada narasumber untuk memperoleh kejelasan, ketimbang kemudian membuat laporan yang 
menyesatkan akibat kekurangan informasi.

Kedua, dokumentasi topik masalah lingkungan hidup yang menarik dapat membantu liputan yang dilakukan pada masa depan. Disarankan agar menyimpan kliping surat kabar dan tulisan yang dapat dijadikan bahan untuk laporan penyidikan (investigative reporting) kemudian hari. Investigative reporting ada kalanya merupakan cara yang tepat untuk menangani masalah lingkungan, seperti ketika dalam suatu laporan tentang pencemaran udara di Kairo, Mahmoud Abdel Aziz dari harian Al Ahram, Mesir, harus mengumpulkan jumlah mobil, truk, dan bus di jalan dari Departemen Lalu-Lintas. Ia bahkan banyak mengandalkan anggota keluarga atau kawan-kawannya untuk memperoleh informasi yang mungkin tidak selalu bisa diperoleh lewat saluran-saluran resmi. Kemudian ia harus mendapatkan analisis kimia tentang mutu udara dari laboratorium pencemaran udara di Pusat Penelitian Nasional. Ia juga memperoleh informasi mengenai jumlah bahan bakar yang digunakan dalam tahun itu dari Departemen Perminyakan. Kemudian ia harus menghubungi Departemen Kesehatan Masyarakat dan industri pada Fakultas Kedokteran Universitas Kairo untuk memperoleh informasi mengenai akibat dari beberapa komponen di dalam berbagai gas yang dikeluarkan oleh kendaraan bermotor. Partikel-partikel ini mencakup timah hitam, hidrokarbon, dan sebagainya.

Lantas, ia harus menghubungi Departemen meteorologi untuk menambahkan dalam laporan itu keadaan cuaca dan bagaimana cuaca mempengaruhi besarnya pencemaran di Kairo. Ia juga mesti memperoleh foto-foto dan membaca tentang pencemaran udara di dalam berbagai jurnal ilmu pengetahuan dan laporan-laporan. Sampai akhirnya, ia mendapat suatu laporan bagus mengenai masalah pencemaran udara di Kairo. Hasil penelitian khas lainnya yang boleh jadi diperlukan seorang reporter sebagai informasi latar belakang bisa berupa studi tentang akibat partikelpartikel timah hitam terhadap proses mental para pekerja di percetakan yang menggunakan timah hitam dan penelitian tentang akibat pencemaran udara terhadap polisi lalu-lintas yang bertugas delapan jam setiap hari di tengah udara tercemar.

Ketiga, dalam beberapa permasalahan, gaya penulisan liputan lingkungan hidup yang baik umumnya sama dengan gaya penulisan liputan jurnalistik yang baik lainnya. Penulisannya, dengan demikian, diupayakan agar menarik, jelas, dan kompleksitas permasalahan diuraikan secara gamblang dan mudah dipahami. Berikan informasi latar belakang (background information) dalam jumlah yang memadai, dengan logika dan argumentasi yang masuk akal.

Keempat, kejelasan informasi berarti juga kejelasan definisi istilah dan makna penemuan atau argumentasi ilmiah. Informasi lingkungan hidup yang tidak memberikan gambaran jelas hanya akan membingungkan khalayak, mubazir, dan oleh karena itu kadang-kadang lebih baik tidak disiarkan. Wartawan masalah lingkungan harus memiliki kesanggupan untuk memahami informasi teknis dan ilmiah khusus yang canggih dan menuliskan kembali, atau menyunting ulang dalam gaya sederhana yang cocok bagi masyarakat. Hal ini harus dilakukan tanpa menghilangkan satu pun fakta ilmiah.

Pedoman peliputan dan penulisan laporan lingkungan hidup di atas hanyalah sekadar kerangka dasar. Seperti disinggung di muka, penulisan masalah lingkungan tak bisa seragam. Artinya, bergantung pada masalah yang timbul. Acapkali pula penulisan masalah lingkungan berlandaskan sesuatu yang tidak tentu. Misalnya, para pakar mungkin tidak begitu mengetahui sumber-sumber pencemaran yang penting dan berbahaya bagi kesehatan manusia. Acapkali juga dalam isu lingkungan tidak hanya ada satu atau dua sisi, tetapi banyak segi. Dan keprihatinan pada persoalan lingkungan tidak bisa diharapkan akan terjadi dalam satu malam. Kita harus terus-menerus membangun kesadaran masyarakat.

\section{Penutup}

Sesungguhnya, perlindungan lingkungan yang ketat akan mempunyai dampak yang cukup signifikan pada perekonomian masyarakat dan negara. Persoalannya, bagaimana agar 
lingkungan dan pembangunan dapat berjalan seiring. Bagaimana pembangunan dapat berkelanjutan dan sumber daya alam dapat lebih dipelihara dan bukannya dirusak.

Isu lingkungan, bagaimanapun, memiliki hubungan keterkaitan yang luas. Tidak hanya interrelasi dalam ekosistem, namun terutama juga memberikan dampak yang besar terhadap kehidupan manusia. Maka itu, wartawan lingkungan dituntut memiliki pengetahuan yang cukup mengenai banyak hal, karena persoalan lingkungan, sekali lagi, marupakan persoalan yang rumit, yang bertali-temali. Namun, yang bikin rumit lagi adalah bagaimana persoalan yang sangat serius itu kemudian bisa dilaporkan secara enteng dan menghibur. Sebab, meminjam kata-kata Syubah Asa (1996), tulisan tentang lingkungan seharusnya menyenangkan.

\section{Daftar Pustaka}

Abrar, Ana Nadhya. 1993. Mengenal Jurnalisme Lingkungan Hidup. Yogyakarta: Gadjah Mada University Press.

Asa, Syu'bah. 1996. "Tulisan tentang Lingkungan Seharusnya Menyenangkan”. Dalam Atmakusumah, Maskun I., Warief D.B. (ed.). Mengangkat Masalah Lingkungan ke Media Massa. Jakarta: Lembaga Pers Dr. Soetomo (LPDS) bekerja sama dengan Yayasan Obor Indonesia. Hlm. 32-36.
Assegaff, Djafar H. 1992. "Peranan Pers Didalam Mendukung Pembangunan Berkelanjutan”. Dalam Daya Dukung Lingkungan dan Komunikasi Massa dalam Pembangunan Berkelanjutan. Jakarta: Kelompok Kerja KLH PWI bersama Kantor Menteri Negara KLH. Hlm. 36-38.

Atmakusumah. 1996. "Pengantar: Masalah Lingkungan dan Media Massa”. Dalam Atmakusumah, Maskun I, WariefD.B. (ed.). Mengangkat Masalah Lingkungan ke Media Massa. Jakarta: Lembaga Pers Dr. Soetomo (LPDS) bekerja sama dengan Yayasan Obor Indonesia. Hlm. ix-xv.

Dahlan, M. Alwi. 1992. "Informasi Pembangunan Berkelanjutan”. Dalam Daya Dukung Lingkungan dan Komunikasi Massa dalam Pembangunan Berkelanjutan. Jakarta: Kelompok Kerja KLH PWI bersama Kantor Menteri Negara KLH. Hlm. 32-35.

Kovach, Bill \& Tom Rosenstiel. 2003. Sembilan Elemen Jurnalisme. Penerjemah Yusi A. Pareanom. Jakarta: Pantau.

Oetama, Jakob. 1987. Perspektif Pers Indonesia. Jakarta: LP3ES

Schramm, Wilbur. 1964. Mass Media and National Development: the Role of Information in Developing Countries. Stanford: Stanford University Press.

West, B., P.M. Sandman, M.R. Greenberg. 1995. The Reporter's Environmental Handbook. New Jersey: Rutgers University Press. 
